\title{
全身麻酔中に交互脈を認めた透析患者の手術症例
}

\author{
尾㟝 孝平 丸川 征四郎* 中川秀幸** 田 畑 勉** \\ 井上隆** \\ 真星病院人工透析 - 高気圧療法部 兵庫医科大学集中治療部* 蒼龍会井上病院**
}

key words : 交互脈, 拡張型心筋症, 透析患者, 全身麻酔, 手術中

〈要旨〉

透析患者の手術症例は年々増加し, 弚の手術や麻酔に関するリスクも増大している. 今回, 拡張型心筋症を合併し E CAPD 患者の術中に交互脈が出現した症例を経験したので報告する. 症例は 13 歳女性, CAPD チューブの閉塞が 原因でチューブ再挿入術が施行された。全身麻酔（ペンタゾシン，ミダゾラム，笑気）下に開腹術が施行され, 交互 派は腹腔内操作が始まった直後から出現した。しかし，血行動態は安定しており，心エコーなどのモニター下に手術 は続行された。交互脈は術終了まで続いたが, 麻酔終了時の笑気吸入終了とともに強波と弱波の差がほとんど認めら れなくなり，光の後 2 時間で完全に交互脈は消失した。交互脈は心筋機能障害の一つの徴候とされ，大動脈弁疾患や 拡張型心筋症などの心不全時に多く認められる。しかし, 本例には心不全徴候はなく, 術前に弁疾患も認めなかった。 したがって, 術前に存在した拡張型心筋症が基礎疾患として何らかの誘因となった可能性はあるが, 交互脈の発現の 契機としては手術操作と全身麻酔が大きく関与しているものと考えられた。

\section{Pulsus alternans in a dialysis patient with dilative cardiomyopathy during intra-operative anesthesia}

Kohei Ozaki, Seishiro Marukawa*, Hideyuki Nakagawa**, Tsutomu Tabata**, Takashi Inoue**

Division of Dialysis \& Hyperbaric Oxygen Therapy, Mahoshi Hospital ; Intensive Care Unit, Hyogo College of Medicine* ; Department of Internal Medicine, Department of Anesthesiology, Inoue Hospital**

We present a case on continuous ambulatory peritoneal dialysis (CAPD) who developed pulsus alternans during abdominal surgery.

A 13-year-old female with dilative cardiomyopathy on CAPD underwent partial omentectomy and implantation of a CAPD catheter under general anesthesia (midazolam, pentazocin, nitrous oxide). Pulsus alternans appeared at the start of intra-abdominal procedures, but the surgery was carried out uneventfully under close observation of hemodynamic condition by echocardiographic monitoring. Pulsus alternans persisted throughout the operation, but suddenly disappeared soon after the nitrous oxide gas was turned off at the end of anesthesia.

Pulsus alternans is generally considered a sign of severe left ventricular dysfunction, usually secondary to dilative cardiomyopathy and aortic stenosis. This patient, however, was not in the state of severe heart failure and did not have any valvular disease. Although dilative cardiomyopathy might have been an indirect cause of the pulsus alternans seen in this patient, it was suspected that the occurrence of this pulsus alternans was related to the intra-abdominal procedures and general anesthesia, judging from its appearance and attenuation.

\section{緒言}

人工透析の進歩とともに透析患者の手術症例が年々増 加している.しかし, 透析患者の麻酔に関するリスクファ クターは，非透析患者に比べて明らかに多く，しばしば
重篤である。これらのリスクファクターの中でも拡張型 心筋症は透析患者に合併頻度が高い，拡張型心筋症は術 中心不全をきたす可能性があり，危険な病態といえ $ろ^{1,2)}$. 今回，拡張型心筋症を合併する慢性透析患者の術

尾㠃 孝平 真星病院人工透析部 于 651-12 神戸市北区山田町上谷上字古古谷 12-3 (078-583-7121)

〔受付：平成 6 年 2 月 14 日, 受理：平成 6 年 6 月 18 日〕 
中に，交互脈を認め，その発現と消失に手術操作と麻酔 の関与が示唆されたので報告する。

\section{症例}

13 歳，女性。身長 $146 \mathrm{~cm}$, 体重 $38 \mathrm{~kg}$. 9 歳時に糸球 体腎炎に罹患，11歳で慢性腎不全のために腹膜透析 (CAPD) が開始された。腎不全以外に特記す心゙き既往歴 はない。今回，CAPD カテーテルの閉塞が原因で大網部 分切除とカテーテル再捜入術が行われた。術前の心電図 は左窒肥大と非特異的 ST-T change がみられ（図 1)，
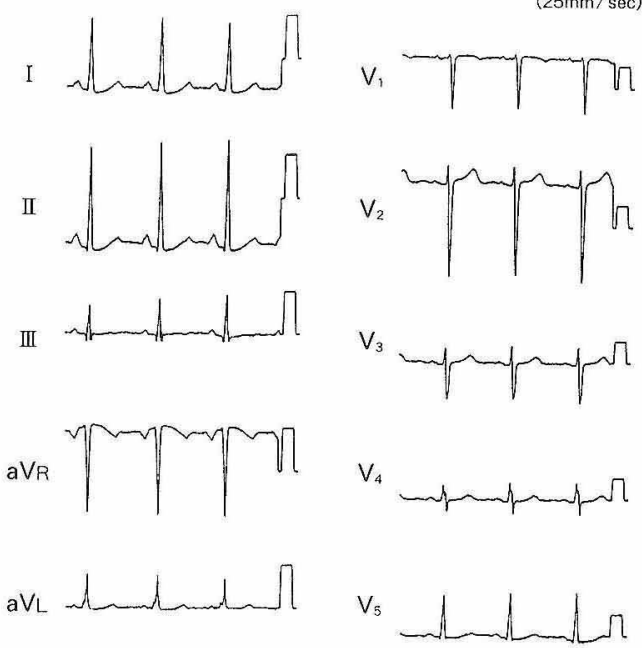

$\mathrm{aVF}$
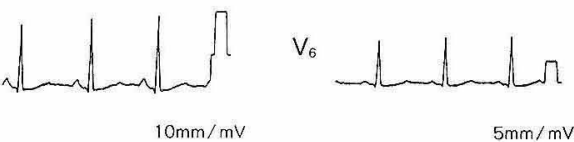

$5 \mathrm{~mm} / \mathrm{mV}$

図 1 Preoperative electrocardiogram
胸部X線所見では肺血管陰影の増強と心拡大 (CTR： 59.3\%) を認めた(図 2 )。心工コー所見でも左室拡大(拡 張末期径 $65 \mathrm{~mm}$, 収縮末期径 $52 \mathrm{~mm}$ )，左室壁運動の全 体的な低下，駆出率 $47 \%$ と左室機能の低下が認められ た。しかし，弁機能には異常を認めず，拡大型心筋症の 診断が下された。その他，術前検査所見，理学所見には 特記す心゙き異常を認めなかった。

麻酔はミダゾラム $2.5 \mathrm{mg}$, ペンタゾシン $20 \mathrm{mg}$, 笑気 $(66 \%)$ を用いた modified neuro-lept anesthesia (m-NLA) で挿管下に行い，筋弛緩剤はべクロニウム5 $\mathrm{mg}$ 孚使用した（図 3 )。麻酔導入後, 術後の血液透析用 にダブルルーメンカテーテルを右大腿静脈に確保し，手 術が開始された。交互脈は手術開始後 15 分に, 癒着を剝
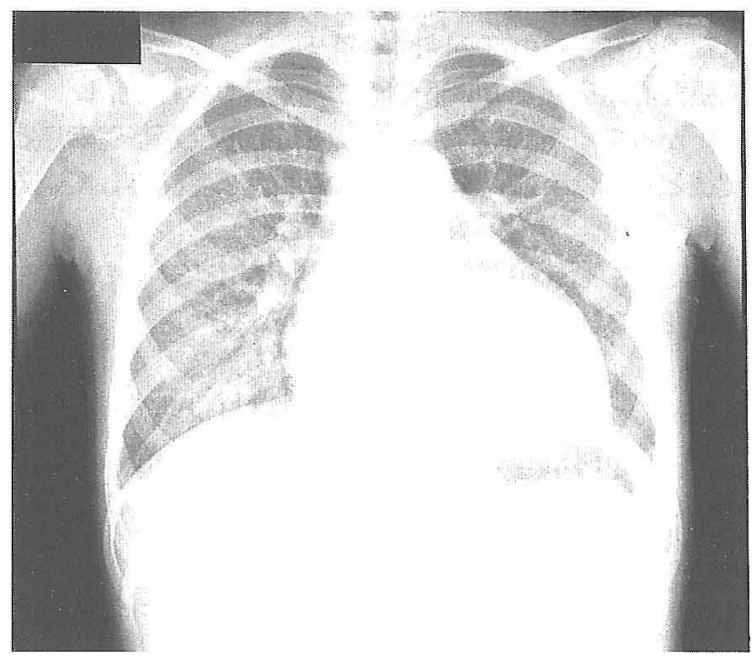

図 2 Preoperative chest X-ray

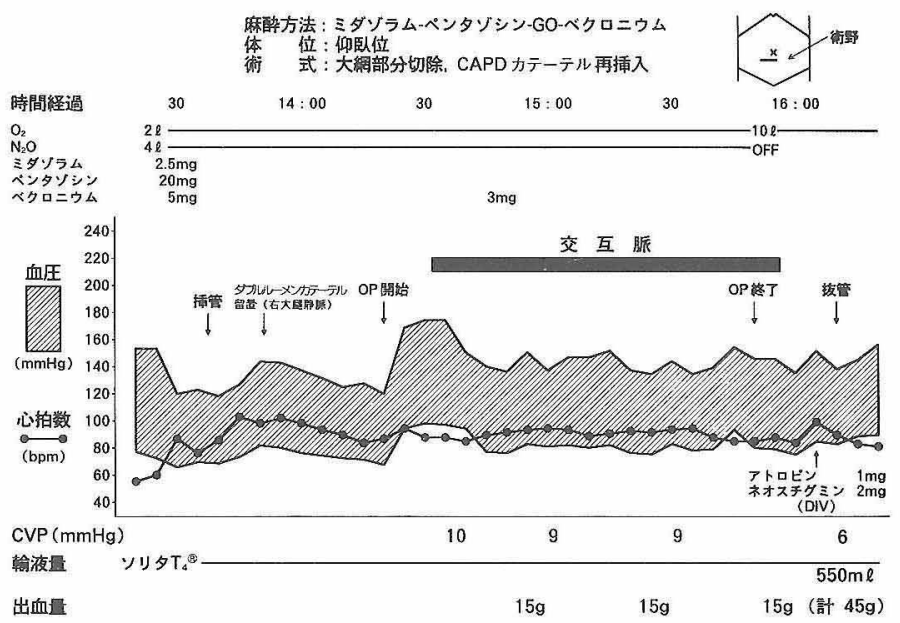

図 3 Anesthetic record 
離するために腹腔内臓器を圧排したときに出現し（図 3 ) , 動脈圧波形とパルスオキシメーターの脈波に観察さ れた。強波は1 $160 \sim 175 / 90 \sim 100 \mathrm{mmHg}$, 弱波は 110〜 130/75〜90 mmHg であり,両波の収縮期圧の差は 40〜 $50 \mathrm{mmHg}$ であった. 心拍数 (HR) は $85 / \mathrm{min}$ で，心電 図上，弱波の後の $\mathrm{R}-\mathrm{R}$ 間隔は強波の後の $\mathrm{R}-\mathrm{R}$ 間隔に比 心゙約 0.04 秒延長していた。しかし，期外収縮等の不整脈 は全く認められず，右房圧も約 $10 \mathrm{mmHg}$ で交代性は認 められなかった(図 4 a). 術中の心エコー所見では強波 と弱波の左室拡張末期径 (LVEDD) はともに $58 \mathrm{~mm}$ で, 拡張末期容量 (LVEDV) も $202 \mathrm{~m} l$ と同量であるが, 左室収縮末期径 (LVESD) は強波 $50 \mathrm{~mm}$, 弱波 $54 \mathrm{~mm}$

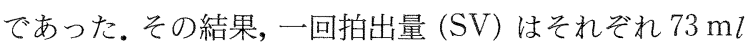
と $45 \mathrm{~m} l$, 駆出率 (EF) は $36 \%$ と $22 \%$ で大きな差が生じ ていた (図 5 a).

一方，血圧および中心静脈圧は図 3 に示すように一定 範囲に保たれ，心不全状態にあるとは考えられなかった。 そこで, 厳重なモニタリングの下で慎重に手術が進めら
れた。手術終了後も交互脈は依然として継続していた。 しかし, 笑気吸入を終了し, 術中の筋弛緩に対してネオ スチグミン等による拮抗を行う前に純酸素で 5 分間換気 をしたところ, 交互脈は突然 $10 \mathrm{mmHg}$ 以内の小さな圧 差しか認めなくなった（図 4 b). ただし，完全に脈圧差 がなくなることはなく, 術後 1 時間経過しても同様の脈 波形を呈していた。この時点のエコー所見では，強波と 弱波の左室内径には僅かな差しか認めず, 強波と弱波の 一回拍出量の差壮術中の $28 \mathrm{~m} l$ から $1 \mathrm{~m} l$ に減少してい た（図 5 b)．完全に交互脈が消失したのは術後 2 時間を 経過した頃であった。

\section{考察}

交互脈は心筋機能障害の一つの徵候とされ，大動脈弁 疾患や拡張型心筋症などの心不全時に多く認められ る ${ }^{3,4)}$. 本例にみられた交互脈は術前の心エコー所見から 判断して弁疾患によるものではなく, 術前に存在した拡 張型心筋症に付随するものと考えられる。しかし，術前 の状態や術中の血行動態からみて本症例が心不全状態に

X0.5 HR: 85 UPC:O F LLTER
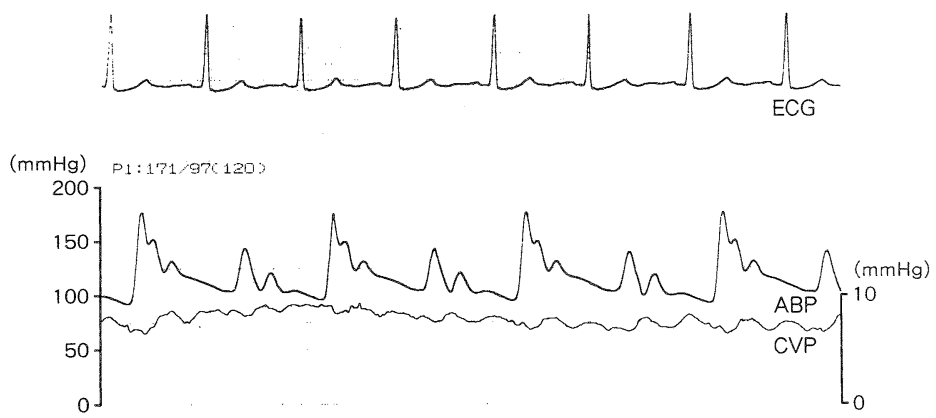

a

$(25 \mathrm{~mm} / \mathrm{sec})$

xo:5 HR:9 WPC: C FILTER

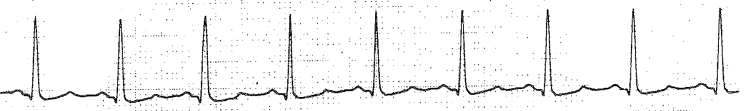

ECG

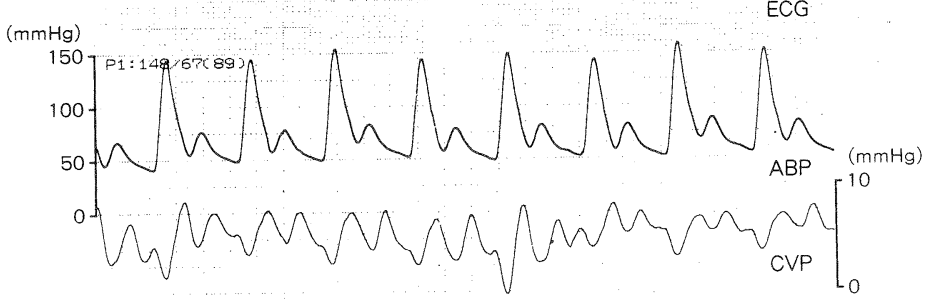

b

$(25 \mathrm{~mm} / \mathrm{sec})$

図 $4 \quad \mathrm{a}$ : at the start of pulsus alternans.

b : 1 hour after the end of the operation.

Electrocardiogram (ECG),

Artery blood pressure (ABP),

Central venous pressure (CVP). 


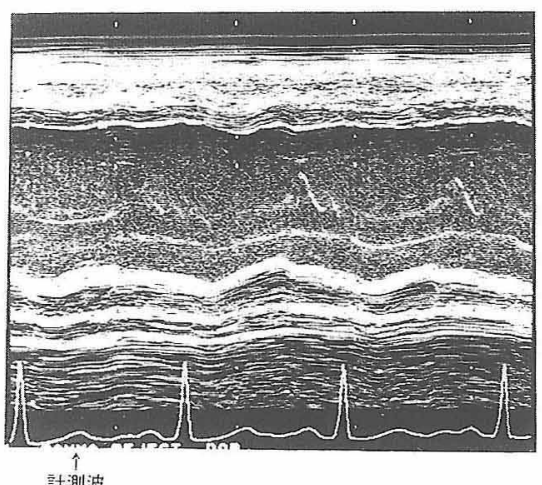

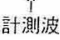

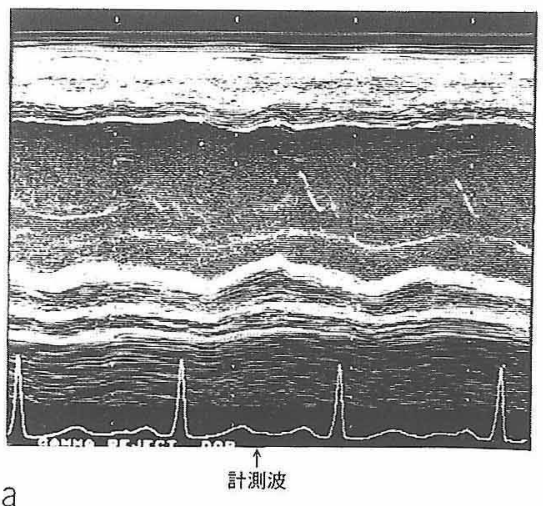

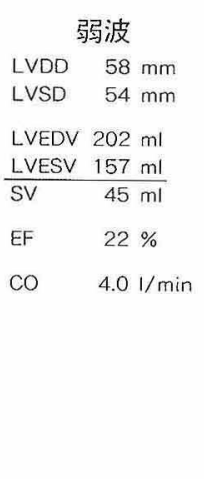

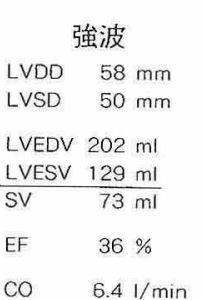
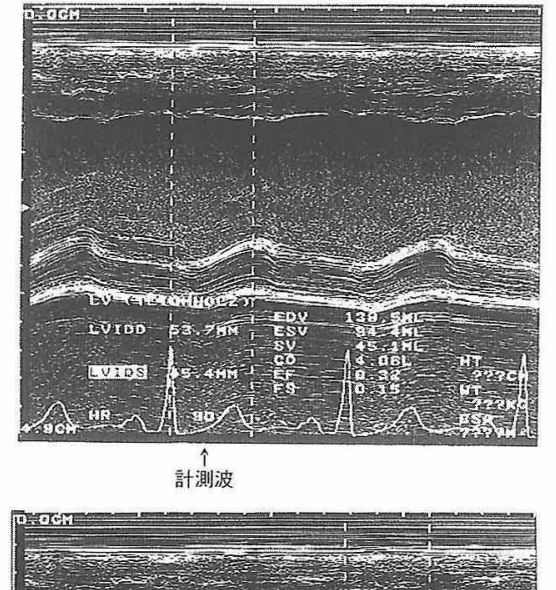

強波

\section{LVDD $53 \mathrm{~mm}$}

LVSD $44 \mathrm{~mm}$

LVEDV $137 \mathrm{ml}$

\begin{tabular}{lll} 
LVESV & $91 \mathrm{ml}$ \\
\hline SV & $46 \mathrm{ml}$
\end{tabular}

EF $\quad 34 \%$

$\mathrm{CO} \quad 4.2 \mathrm{I} / \mathrm{min}$

図 5 a : at the start of pulsus alternans.

b : 1 hour after the end of operation.

B-mode echocardiogram.

あったとは考えられない。

交互脈の病態生理については, 前負荷が一心拍毎に変 化するために強波と弱波が形成されるとした報告5)，あ るいは，心筋の酸素・エネルギー消費の不均衡が存在す るために交互脈が生じるとする報告がある6 。しかし，本 例では右房圧と左室拡張末期径には強波と弱波の間に差 を認めず，前負荷は変化していない。さらに，術中の酸 素飽和度や平均血圧からみて心筋への酸素供給は十分に 保たれており，これらの機序は否定できる。この他にも， 強波と弱波でカルシウムの心筋内流入速度が異なること が原因であるとするもの7)，あるいは，興奮収縮連関の障 害にその機序を求めるもの など，多くの報告がなされ ている。しかし，それぞれの報告で対象や発生状沿が明 らかに異なる。このために複数の機序が存在する可能性 も高く，現在もなお交互脈の病態が解明されたとはいえ ない。透析患者では心筋アミロイド沈着も報告され ${ }^{9)}$, 尿 毒症も拡張型心筋症とともに，本現象と何らかの関連が あるのではないかと推測されるが明らかではない。

一方，交互脈発現の契機としては，心室性期外収縮に 引き続いて交互脈が発生したとする報告 ${ }^{(0)}$ や筋虚血と
関係したとする報告 ${ }^{11)}$ が多い。また, 前負荷を大きく減少 させる処置,すなわち, 硝酸イソソルビドの使用 ${ }^{12}$ や下大 静脈バルーン閉塞時に発生したとする報告 ${ }^{13)}$ がある。こ の症例も腹腔内操作に移ったときに発生しており，術中 の下大静脈の圧迫が発生の契機となった可能性が高い。

交互脈の消失や脈圧差の減弱についての報告は，亜硝 酸剂の吸入時に減弱したという報告 ${ }^{14)}$ と、ニトログリセ

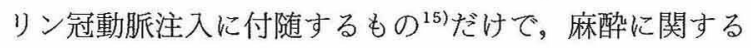
ものはない。しかし，笑気吸入の中止に続いて交互脈が 消失したことから考えて，笑気による心筋抑制 ${ }^{16)}$ の解除， あるいは覚醒反応による内因性カテコラミンの増加が交 互脈終息の要因となった可能性が高い。現時点で因果関 係を明らかにすることは不可能であるが，麻酔終了時に 交互脈がほぼ消失したことから，本例では麻酔が交互脈 発生の機序に深く関与していることが示唆された。

さて，術前より心不全状態にある患者に交互脈が発生 した場合は，危険な徴候として直ちに手術を中止する， あるいは心筋収縮力により影響の少ない麻酔法に変更す るべきかもしれない ${ }^{17)}$ 。しかし, Hada ら ${ }^{10)}$ が交互脈の発 生と心不全の重症度には相関がないと報告するように心 
不全以外に交互脈が発生しやすい種々の因子があると考 えられる，他の交互脈についての報告をみても，すべて が心不全状態に付随するものではない.したがって, 手 術や麻酔が過度に循環動態を抑制しない限り, 本例のご とく十分なモニタリングと慎重な手術手技のもとに手術 を続行してもよいと考える，ただし，常に心不全を前提 とした準備を怠るべきではない.

\section{結語}

1。拡張型心筋症を合併した 13 歳女性の CAPD 患者 の手術中に交互脈を経験した。

2. 交互脈は腹腔内操作時に発生し, 術中継続した。 全身麻醉終了に際し笑気吸入を終了したところ交互脈は 突然減弱し, 術後 2 時間で消失した。

3. 交互脈は尿毒症性の拡張型心筋症に付随するもの と考えられるが, 発現の契機として全身麻酔と腹腔内操 作が関与していると考えられた。

な押, 本論文の要旨は, 第 1 回腎不全外科研究会（東京） で発表した.

\section{文献}

1) Parfrey $P$, Griffith $S$, Harnett J, Taylor R, King A, Hand J, Barre PE: Outcome of congestive heart failure, dilative cardiomyopathy, hypertrophic hyperkinetic disease, and ischemic heart disease in dialysis patient. Am J Nephrol 10: 213 $-221,1990$

2) Renger A, Muller M, Jutzler GA, Bette L: Echocardiographic evaluation of left ventricular dimensions and function in clonic hemodialysis patients with cardiomegaly. Clinical Nephrology $21: 164-168,1984$

3) Braunwald $E$ : Clinical aspects of heart failure. In "Heart Disease" ed Braunwald E, p 445-456, W. B. Saunders company, Philadelphia PA, 1992

4) Wynne J, Braunwald E: The Cardiomyopathies and Myocarditis, Toxic, Chemical and Physical Damage to the Heart. In "Heart Disease" ed Braunwald E, p 1394-1404, W.B. Saunders company, Philadelphia PA, 1992

5) Chandraratna PAN, Langevin E, Langevin J : Pulsus alternans induced by trinitrate paste in a patient with alcoholic cardiomyopathy. Br Heart J 41 : 354-355, 1979

6) Werber KT, Janicki JS, Sundram P : Myocardial energetics: experimental and clinical studies to address its determinants and aerobic limit. Basic Res Cardiol 84 : 237-246, 1989

7) Hashimoto H, Suzuki K, Miyake S, Nakashima $\mathrm{M}$ : Effect of calcium antagonists on the electrical alternans of the ST segment and on associated mechanical alternans during acute coronary occlusion in dog. Circulation 68 : 667-672, 1983

8) Hasenfuss G, Holubarsch C, Heiss HW, Bonzel T, Funfack M, Revenauch M, Meinertz T, Just H : Hemodynamics and myocardial oxygen metabolism of pulsus altermans in patients with dilative cardiomyopathy. Clin Cardiol 10:323-327, 1987

9）本間則行，下条文武，荒川正昭：透析アミロイド症 と心臟障害. 臨床透析 10:91-95, 1994

10) Hada $Y$, Wolfe $C$, Craige $E$ : Pulsus alternans determined by biventricular simultaneous systolic time intervals. Circulation 65 : 617-626, 1982

11) Elbaum DM, Banka VS : Pulsus alternans during spontaneous angina pectoris. Am J Cardiol 58 : 1099-1100, 1986

12) Matsuhashi $H$, Onodera $S$, Hasebe $N$, Maruyama J, Honda H, Yamashita H, Tobise K : Transient pulsus alternans induced by isosorbide dinitrate : echocardiographic and hemodinamic evidence of reduced venous return-a case report. Angiology 42: 504, 1991

13) Bashore TM, Walker S, Van Fossen D, Shaffer $\mathrm{PB}$, Fontana ME, Unverferth DV : Pulsus alternans induced by inferior Vena Cava occlusion in man. Catht Cardiovasc Diagn $14: 24,1988$

14) Cheng TO, Leet $C J:$ Pulsus alternans its response to amyl nitrite inhalation. Angiology $35: 115-121$, 1984

15) Ring ME, Kern MJ, Genovery $H$, Serota H, Vandormael $\mathrm{M}$ : Attenuation of pulsus alternans during coronary angiography. Catht Cardiovasc Diagn 20 : 193-195, 1990

16) Hickey RF, Eger El II : Circulatory pharmacology of inhaled anesthetics. In "Anesthesia 2 nd edition. Volume 1" ed Millaer RD. p 656-659, Churchill Livingstone Inc, Edinburgh, 1986

17）竹中智明, 野見山延, 岡田昌平, 三好 進, 村上雅 子, 渡辺 敏, 田中 亮: 心筋症合併例の麻酔の検 討. 麻酔 $39 ： 644-650,1990$ 